\title{
Comparison of Heavy Metal Residues on Sheep that Grazing in Landfill Area Before and After Elimination Process
}

\author{
Rahayu $\mathrm{P}^{1}$, Munawaroh $\mathrm{IS}^{2}$, Elok $\mathrm{K}^{1}$ \\ ${ }^{1}$ Quality Control Laboratory and Certification of Animal Products, Ministry of Agriculture \\ Jl Pemuda no.29 A, Bogor, West Java, Indonesia \\ ${ }^{2}$ Indonesian Center for Animal Research and Development, Ministry of Agriculture RI \\ Jl. Raya Pajajaran Kav.E-59, Bogor, West Java, Indonesia \\ puji_latif@yahoo.co.id; iif.syarifah@gmail.com
}

\begin{abstract}
Determination of heavy metal content on livestock that grazing in landfill area is important to determine the potential effects of pollutants and for the quantification of residues that would be consumed by humans. Four sheep $(\mathrm{n}=4)$ aged 6-12 months with weight $\pm 25 \mathrm{~kg}$ are selected to be used as a sample. The selected sheep are known grazing in an area of landfill area from birth. As control was used one sheep that grazing normally. The first two sheep were slaughtered and some organs were taken (meat, blood, feces, skin, kidneys, liver, feathers, intestines, and fat). Those organs were tested for the presence of residues of heavy metals using Atomic Absorption Spectrophotometer (AAS). Two last sheep taken from the landfill area were grazed in regular grassland. After three months, the second group of sheep were slaughtered and treated similar to the first group of sheep and tested against heavy metal residues using AAS. Residue level of four heavy metals $(\mathrm{Cd}, \mathrm{Pb}, \mathrm{Hg}$, As) from the sample of the first group of sheep was determined and the results were compared with the level of heavy metal residues from the sample of second group of sheep. The results show a significant difference $(\mathrm{P}<0.05)$ of the heavy metals residue content of $\mathrm{Cd}, \mathrm{Pb}, \mathrm{Hg}$ and $\mathrm{As}$ in the sample before and after elimination process. Efforts of elimination of pollutant residues by moving the livestock from grazing in landfill area to regular grazing could be one of the methods to reduce the levels of heavy metal residues in livestock.
\end{abstract}

Key Words: Heavy Metal, Landfill Area, Sheep, Atomic Absorption Spectrophotometer

\section{INTRODUCTION}

Meat and meat products are important for human diet because they provide a great part of nutrients, including the necessary trace elements. Heavy metals from human activities pollution sources are continuously released into aquatic and terrestrial ecosystems and therefore, the concern about the effect of anthropogenic pollution on the ecosystems is growing. Heavy metals contamination is a serious threat because of their toxicity, bioaccumulation and biomagnifications in the food chain (Demirezen \& Uruc 2006).

Food is one of the three basic needs of human life in addition to clothing and shelter. Food consumed by people must be certainly good and healthy for the human body. According to (Fardiaz 1992), there are four major problems related to food safety in Indonesia, found many on food products that do not meet the health requirements; still many cases of disease and poisoning through food that most have not been reported and on identified the cause; many production and distribution facilities of food that do not meet the requirements, particularly small industries and home industries, and street food sellers, as well as lack of consumers' knowledge and concerns about food safety.

Lamb is one source of animal protein for human nutrition and preferred by consumers (Sudarmono \& Sugeng 2003). Although number of consumers who prefer lamb was not as many as in the beef and chicken, but it remains a serious consideration to food safety. Especially if people knew high protein content in lamb, their enthusiasm will increase. Therefore, it should be noted the maintenance of these sheep as an initial step to maintain food security through animal health. 
Lambs were type of grass-eating animals belonging to small ruminants. Sheep breeding in Indonesia is largely grounded and some are reared in pasturelands. In some locations, not a few farmers who let the sheep grazed in the vicinity of landfills. This is likely due to the more expensive feed and farmers who are reluctant to seek grass, so the animals are left scavenging in the landfill.

Along with the current development, the level of pollution is a global problem and cause significant contamination levels of either to the soil, animals, and plants (Nwude et al. 2010), it also caused the presence of residues in contaminated animal or plant products. Food safety, particularly food from animal currently is also getting serious attention. In some areas, especially in Java, due to the limited grazed land, a number of livestock farmers raise cattle in landfill area. Due to the increasing industrial activities waste produced dumped into landfill areas, it increases the presence of heavy metals and due to metal properties which are accumulated, it cause the livestock scavanging in the landfill areas will be exposed to heavy metals in high quantities. Studies on the effect of heavy metal residues in livestock are mostly emphasized on livestock that have a history of exposure to high levels of the heavy metal residues, as in livestock grazing in an industrial environment and livestock scavanging in landfill area as well (Ogabiella et al. 2010).

The risk associated with the exposure to heavy metals present in food product had aroused concern widespread in human health. Improvements in the food production and processing technology increased the chances of contamination of food with various environmental pollutants, especially heavy metals. Ingestion of these contaminants by animals causes deposition of residues in meat. Due to the grazing of cattle on contaminated soil, higher levels of metals recorded the levels of toxic metals (lead and cadmium) in meat product exceeding recommended limits (Akan et al. 2010). Arifin et al. 2003 reported that livestock products derived from cattle slaughter grazed in landfill areas were detected containing residues of heavy metals, especially $\mathrm{Pb}, \mathrm{Hg}$ and $\mathrm{Cd}$ in an amount above the allowable Maximum Residue Limit (MRL).

The aim of this study was to assess heavy metal residues on some organs taken from sheep scavenge from the landfill area and the elimination efforts to reduce heavy metal residues from cattle that grazing around landfill area.

\section{MATERIAL AND METHODS}

\section{Variables}

The variables measured were: (1) The presence of heavy metal residues on some organs are taken (meat, blood, feces, skin, kidneys, liver, feathers, intestines and fat) from sheep originating from the landfill; (2) The presence of metal residues on some organs are taken (meat, blood, feces, skin, kidneys, liver, feathers, intestines and fat) of lamb removed from landfill location and fed with elephant grass and commercial concentrate and was slaughtered after three months.

\section{Matherials}

The study was carried out between the periods of March 2015 to July 2015. Samples were collected from landfill area, Purwakarta District, West Java, Indonesia. Four sheep aged 6-12 months with average weight \pm 25 were used as samples. Selected lambs were known grazing in the landfill area from birth. As control was used one sheep that grazing normally. The first two sheep and control sheep were slaughtered and some organs were taken (meat, blood, feces, skin, kidneys, liver, feathers, intestines, and fat). Those organs were analysed for the presence of residues of heavy metals using Atomic Absorption 
Spectrophotometer (AAS). Last two sheep were removed from the landfill area and placed in grassland and grazed as usual. The sheeps were fed of elephant grass and commercial concentrate. After three months the second group of sheeps were slaughtered and some organs which were similar to the first group of sheep were taken and analysed for the heavy metal residues using AAS. As control $(n=1)$ was used one sheep that grazing normally. Residue levels of four heavy metals $(\mathrm{Cd}, \mathrm{Pb}, \mathrm{Hg}$, As) from the sample of first group of sheep are determined and the results are compared with the level of heavy metal residues from the sample of second group of sheep.

\section{Equipment}

The equipments used were Atomic Absorption Spectrophotometer (AAS) Varian Type AA240FS incorporating cathode lamps with specifications of heavy metal, Microwave Acid Digestion Apparatus, tube vessel, the balance sheet, volumetric flask of $50 \mathrm{~mL}$, parafilm, funnel glass, and a mechanical pipette respectively.

\section{Sample analysis}

Destruction carried out was wet destruction using a solvent in the form of concentrated nitric acid $\left(\mathrm{HNO}_{3} 65 \%\right)$, a solution of hydrogen peroxide $\left(\mathrm{H}_{2} \mathrm{O}_{2} 30 \%\right)$, a solution nitric acid $\left(\mathrm{HNO}_{3} 0.1 \mathrm{~N}\right)$, deionized water, standard solution of $\mathrm{Cd}, \mathrm{Pb}, \mathrm{Hg}$ and As.

Tubes vessel was placed on the balance sheet, then each sample of 0.3 grams. Put in a solution of nitric acid $\left(\mathrm{HNO}_{3}\right) 65 \%$ as much as $8 \mathrm{~mL}$ and hydrogen peroxide $\left(\mathrm{H}_{2} \mathrm{O}_{2}\right) 30 \%$ as much as $2 \mathrm{~mL}$. The tube vessels are put into the Microwave Acid Digestion Apparatus to carry out wet destruction process. Sample preparation solution that has been destructed was transferred to volumetric flask $50 \mathrm{~mL}$ with the aid of a glass funnel. Thereafter, deionized water is added to the limit tera.

\section{Measurement of standard series and sample of test}

Measurement of the standard series and sample of test were carried out using AAS and optimized by adjusting the lights and signals. Once optimized, one by one standard solution of $\mathrm{Cd}, \mathrm{Pb}, \mathrm{Hg}$ and $\mathrm{As}$ were aspirated into AAS. After standard solution, the sample solution was aspirated into the AAS and measured three times as replications so that the readings can be known for accuracy.

\section{Data analysis}

Data on the amount of heavy metal content were statistical analysis using the student $t$ test (at $\mathrm{P}<0.05)$.

\section{RESULTS AND DISCUSSION}

The concentrations of heavy metals residues on some organs are taken (meat, blood, feces, skin, kidneys, liver, feathers, intestines and fat, respectively) from sheep originating from the landfill before and after elimination process are presented in Table 1. After elimination process concentration of heavy metals residue were reduse significantly. The concentration of heavy metal residues on some organ from control sheep are presented in Table 2 including the comparison of heavy metal residues on sheep that grazing in landfill area with control sheep that grazing normally. 
Table 1. Heavy metal concentrations of samples before and after elimination process

\begin{tabular}{|c|c|c|c|c|c|c|c|c|}
\hline \multirow{3}{*}{ Sample } & \multicolumn{8}{|c|}{ Heavy metals concentration $($ mean \pm SD $(\mathrm{ppm}))$} \\
\hline & \multicolumn{2}{|c|}{ Cadmium $(\mathrm{Cd})$} & \multicolumn{2}{|c|}{ Lead $(\mathrm{Pb})$} & \multicolumn{2}{|c|}{ Mercury $(\mathrm{Hg})$} & \multicolumn{2}{|c|}{ Arsen (As) } \\
\hline & Before & After & Before & After & Before & After & Before & After \\
\hline Meat & $2.34 \pm 0.92 * *$ & $0.62 \pm 0.21 *$ & $2.92 \pm 0.84 * *$ & $1.32 \pm 0.68 *$ & $0.60 \pm 0.43 * *$ & $0.09 \pm 0.07 *$ & $1.19 \pm 0.32^{* *}$ & $0.87 \pm 0.55^{*}$ \\
\hline Blood & $1.03 \pm 0.23 * *$ & $0.23 \pm 0.15^{*}$ & $1.30 \pm 0.87 * *$ & $0.43 \pm 0.39 *$ & $0.57 \pm 0.32 * *$ & $0.21 \pm 0.18^{*}$ & $1.28 \pm 0.28 * *$ & $0.84 \pm 0.61 *$ \\
\hline Feces & $0.35 \pm 0.61 * *$ & $0.01 \pm 0.04 *$ & $2.10 \pm 0.43 * *$ & $1.60 \pm 0.67 *$ & $0.17 \pm 0.12 * *$ & $0.09 \pm 0.08 *$ & $2.32 \pm 0.15^{* *}$ & $1.10 \pm 0.69^{*}$ \\
\hline Skin & $1.34 \pm 0.52 * *$ & $0.46 \pm 0.28 *$ & $2.07 \pm 1.12 * *$ & $1.34 \pm 0.66 *$ & $0.19 \pm 0.08 * *$ & $0.14 \pm 0.06^{*}$ & $2.27 \pm 0.41 * *$ & $0.92 \pm 0.81 *$ \\
\hline Kidney & $1.22 \pm 0.74 * *$ & $0.63 \pm 0.41^{*}$ & $4.36 \pm 0.41 * *$ & $1.45 \pm 1.24 *$ & $0.53 \pm 0.38 * *$ & $0.30 \pm 0.21 *$ & $1.25 \pm 0.99 * *$ & $0.84 \pm 0.41 *$ \\
\hline Liver & $1.05 \pm 0.82^{* *}$ & $0.92 \pm 0.62 *$ & $2.28 \pm 1.13^{* *}$ & $1.69 \pm 0.97 *$ & $0.48 \pm 0.42 * *$ & $0.33 \pm 0.16^{*}$ & $1.32 \pm 0.12^{* *}$ & $0.64 \pm 0.48^{*}$ \\
\hline Feathers & $1.66 \pm 1.04^{* *}$ & $0.03 \pm 0.04 *$ & $3.95 \pm 2.52^{* *}$ & $1.01 \pm 0.84 *$ & $0.51 \pm 0.43^{* *}$ & $0.45 \pm 0.36^{*}$ & $3.46 \pm 0.18^{* *}$ & $0.47 \pm 0.22 *$ \\
\hline Intestines & $1.09 \pm 0.87 * *$ & $0.45 \pm 0.31 *$ & $3.37 \pm 1.67 * *$ & $1.05 \pm 0.28 *$ & $0.33 \pm 0.21 * *$ & $0.23 \pm 0.21 *$ & $1.13 \pm 0.49 * *$ & $0.94 \pm 0.18^{*}$ \\
\hline Fat & $1.47 \pm 0.54^{* *}$ & $0.65 \pm 0.29 *$ & $3.31 \pm 2.42^{* *}$ & $1.15 \pm 0.96 *$ & $0.28 \pm 0.25^{* *}$ & $0.18 \pm 0.15^{*}$ & $2.14 \pm 1.02^{* *}$ & $1.04 \pm 0.44 *$ \\
\hline
\end{tabular}

*Significant difference $(\mathrm{p}<0.05)$ to the heavy metals residue content of $\mathrm{Cd}, \mathrm{Pb}, \mathrm{Hg}$ and $\mathrm{As}$ in the sample before and after elimination process; **Maximum Residue Limit (MRL) for meat (m) and offal (o) : $0.3 \mathrm{ppm}(\mathrm{m})$ and $0.5 \mathrm{ppm}(\mathrm{o})$ for Cd; $1 \mathrm{ppm}(\mathrm{m} \& \mathrm{o})$ for $\mathrm{Pb} ; 0.03 \mathrm{ppm}(\mathrm{m} \& \mathrm{o})$ for $\mathrm{Hg}$; $0.5 \mathrm{ppm}(\mathrm{m})$ and 1 ppm (o) for As, according to SNI 7367:2009 
Table 2. Heavy metal concentrations of samples from the control sheep

\begin{tabular}{|c|c|c|c|c|}
\hline \multirow{2}{*}{ Sample } & \multicolumn{4}{|c|}{ Heavy metals concentration (mean (ppm)) } \\
\hline & Cadmium $(\mathrm{Cd})$ & Lead $(\mathrm{Pb})$ & Mercury $(\mathrm{Hg})$ & Arsen (As) \\
\hline Meat & $0.03 * * *$ & $0.62 * * *$ & ND & $0.22 * * *$ \\
\hline Blood & $0.06^{* * *}$ & $0.23^{* * *}$ & ND & $0.13^{* * *}$ \\
\hline Feces & $0.01 * * *$ & $0.31 * * *$ & ND & $0.40 * * *$ \\
\hline Skin & $0.02 * * *$ & $0.46^{* * *}$ & ND & $0.24 * * *$ \\
\hline Kidney & $0.02 * * *$ & $0.63^{* * *}$ & ND & $0.34 * * *$ \\
\hline Liver & $0.04 * * *$ & $0.92 * * *$ & ND & $0.59^{* * *}$ \\
\hline Feathers & $0.06^{* * *}$ & $0.83^{* * *}$ & ND & $0.71 * * *$ \\
\hline Intestines & $0.02 * * *$ & $0.25 * * *$ & ND & $0.25^{* * *}$ \\
\hline Fat & $0.04 * * *$ & $0.45^{* * *}$ & ND & $0.12^{* * *}$ \\
\hline
\end{tabular}

ND: Not detected with limit of detection for mercury $0.0021 \mathrm{ppm}$; ***Significant difference $(\mathrm{p}<0.05)$ of the heavy metals residue content of $\mathrm{Cd}, \mathrm{Pb}, \mathrm{Hg}$ and $\mathrm{As}$ in the sample of control sheep and grazed sheep that grazing in the landfill area

From the Table 1 above, can be seen that the samples of sheep before the elimination process of heavy metal residue levels of $\mathrm{Cd}, \mathrm{Pb}, \mathrm{Hg}$ and As were above the maximum contaminant according to the requirement of Indonesian Standar for Heavy Metal Residues (SNI 7387: 2009). Whereas in the group of sheep that undergone elimination process, heavy metal residues in some organs decreased although not all of them were under the requisite maximum contaminant standard. Analysis of variance shows that a significant difference between the groups of sheep before and after a process of elimination $(P<0.05)$. From these data, indicates that the process of elimination residues in livestock by removing from landfill areas and grazing normally was able to reduce the level of heavy metal residues although it was not able to eliminate the existence of heavy metal residues totally.

Landfill area utilized in this experiment is also used by some farmers in similar condition some other cities, but the livestock grazing in the environment of landfill area can also give adverse impacts. According to Arifin et al. (2003) livestock grazing in landfill area produces food products that are not safe. It is because the waste contains toxic materials that get into the food chain through livestock consumed.

According to Wardhayani et al. (2006), landfill area is often used by the community as the location of livestock grazing, because the waste can be used as feed for livestock. The people's tought raise cattle in a landfill area with consideration that the organic waste dumped still has quite high nutritional value so that it can be used as animal feed. The livestock grazed in the landfill area usually ruminant such as sheep, goats, and cattle. Livestock consuming waste from the landfill area have a high risk of exposure to toxic materials.

Heavy metals enter through feed material, ultimately passage into the tissue (Baykov et al. 1996). Lead, cadmium, mercury and arsenic are among the main toxic metals which accumulate in food chains and have a cumulative effect (Cunningham \& Saigo 1997). Heavy metals often have direct physiologically toxic effects and are stored or incorporated in living tissues (Baykov et al. 1996).

A study carried out by John \& Jeanne (1994) showed that levels of arsenic, cadmium, mercury and lead were detected in several tissues of goats; the results showed that the levels of the above metals were found to be very high and generally above the permissible 
level. Similarly, the distribution of some heavy metals in the tissues of some organs were detected, the most affected organs, which showed higher level s of trace metals, were livers, kidneys and small intestines (Horky et al. 1998).

Heavy metals are dangerous components because the heavy metals can accumulate in the body tissues of animals and humans. Heavy metals such as lead $(\mathrm{Pb})$ and cadmium $(\mathrm{Cd})$ are sourced from the polluted environment. Heavy metals $\mathrm{Pb}$ and $\mathrm{Cd}$ are a category of toxic and hazardous wastes, so that when the dose exceeds normal then it can lead to poisoning. Heavy metals do not give direct effect in the short term to human health but health problems will occur in the long term due to the accumulation of heavy metal in body tissues. Some of the health problems in humans as a result of the heavy metals lead $(\mathrm{Pb})$ and cadmium $(\mathrm{Cd})$ are anemia, a disorder in various organs, as well as decreased intelligence, and the children are the main groups that are vulnerable to heavy metal poisoning in food. The cause of the increase $\mathrm{Cd}$ pollution occured is similar to the increase of $\mathrm{Pb}$, smoke from vehicle. In addition, (Sudarmaji et al. 2006) said that most of the contaminants from the metal $\mathrm{Cd}$ derive from cigarette. According to Iwegbue et al (2008), the content of $\mathrm{Cd}$ in ash and smoke is 0.833 and $0.40 \mathrm{ppm}$ respectively. Similarly $\mathrm{Pb}, \mathrm{Cd}$ metals are most absorbed through breathing, that is about 10-40\% depending on the region condition. In addition, heavy metal $\mathrm{Cd}$ pollution may occur in livestock through the air, contaminating feed containing high mineral phosphate, through grains or through water and soil. In the maintenance system which tends to be released, and cause the accumulation of heavy metals $\mathrm{Cd}$ in livestock (Harlia et al. 2006).

$\mathrm{Pb}$ contaminants can be naturally found in the soil in the form of $\mathrm{Pb}$ arsenate (Fardiaz 1992). Liquid waste as a pigment or dye in the cosmetics industry, solid waste such as batteries and plastic waste are also a source of $\mathrm{Pb}$ contamination. Besides that, $\mathrm{Pb}$ can also be produced from gas waste through incomplete combustion of large vehicles transporting garbage to the landfill area. These incomplete combustion will produce $\mathrm{PbBrCl}$, $\mathrm{PbBrCl} .2 \mathrm{PbO}$, tetraethyl $\mathrm{Pb}$ that would eventually become the largest source of $\mathrm{Pb}$ contaminants through the air (Gusnita 2011).

According Wardhayani et al. (2006), lead $(\mathrm{Pb})$ is a heavy metal mineral and potential to become toxic if it accumulates in the body, so it could potentially be toxic in organisms. The entry of lead $(\mathrm{Pb})$ into the animal's body can be through the digestive tract (gastrointestinal), respiratory tract (inhalation), and penetration through the skin (topical). Cattles grazed in the landfill area would be very dangerous if then used as a human food because $\mathrm{Pb}$ will accumulate in human body, which can cause health problems.

$\mathrm{Hg}$ the first ranks in terms of its toxic properties compared to other heavy metals, it followed by Cd, Ag, Ni, Pb, As, Cr, Sn, Zn (Fardiaz 1992). Most of toxicity caused by several types of heavy metals such as $\mathrm{Pb}, \mathrm{Cd}$, and $\mathrm{Hg}$ is due to its ability to close the active site of the enzyme in the cell. The toxicity of $\mathrm{Hg}$ in this case is divided into two parts, namely the toxicity of organic and inorganic. In the form of inorganic, $\mathrm{Hg}$ is bound to one or more carbon atoms, whereas in organic form, with short alkyl chains. The toxicity of inorganic $\mathrm{Hg}$ usually causes the patients to experience tremors. If it continues, it may cause a reduction in hearing, vision, or memory.

Arsenic compounds are very difficult to be detected because they do not have a distinctive taste or characteristics of another prominent exposure. Symptom of arsenic poisoning compounds is primarily a pain in the throat, difficulty swallowing, after stomach pain and vomiting. The impact of arsenic exposure on humans is cancer, particularly lung and liver cancers. Exposure to arsenic in the air can also cause the formation of skin cancer (Palar 2004)

The process of elimination is an action or effort aimed to reduce the content of certain substances from the object. Efforts to eliminate the heavy metal contamination in livestock 
grazed in the landfill area can be done by quarantining or moving the livestock to grazing area before slaughter (Darmono 1995). At the time of the elimination process, the livestock should be given conventional feed in the form of forage grass and also a commercial concentrate feed. This elimination effort could not be said eliminating the heavy metal residues perfectly, but the results can be said as the elimination which would reduce the levels of heavy metal residues.

\section{CONCLUSION}

The presence of heavy metal content in the samples of sheep grazing in the landfill area that exceed the threshold is an alert to the need to improve public awareness of food safety from livestock sources. Heavy metal residues presented in all meat and body parts of other sheep can pose a health hazard to humans. The effort of elimination by moving the livestock from grazing in landfill area to regular grazing was proven process to be one of effective ways to reduce the residue levels in livestock. It needs a regulation that regulates prohibition of livestock grazing in landfill area.

\section{REFERENCES}

Akan JC, Abdulrahman FI, Sodipo OA, Chiroma YA. 2010. Distribution of heavy metals in the liver, kidney and meat of beef, mutton, caprine and chicken from Kasuwan, Borno State, Nigeria. Res J Appl Sci Eng Techol. 2:743-748.

Arifin M, Setiani BE, Dwiloka B. 2003. Residu pestisida pada hati sapi yang digembalakan di tempat pembuangan sampah (TPA) Jati Barang Kota Semarang. Prosiding Seminar Nasional Teknologi Peternakan dan Veteriner. Bogor (Indonesia): Puslitbang Peternakan.

Baykov BD, Stoyanov MP, Gugova ML. 1996. Cadmium and lead bioaccumulation in male chicken for high food concentrations. Toxicol Environ Chem. 54:155-159.

Cunningham WP, Saigo BW. 1997. Environmental Science a Global Concern. 4th edition. New York (USA): WMC Brown Publisher. p. 389.

Darmono. 1995. Logam dalam Sistem Biologi Mahluk Hidup. Jakarta (Indonesia): Universitas Indonesia

Demirezen O, Uruc K. 2006. Comparative Study of trace elements in certain fish, meat and meat products. Food Chemistry 32:215-222.

Fardiaz S. 1992. Polusi Air dan Udara. Bogor (Indonesia): PT Kanisius.

Gusnita D. 2011. Pencemaran logam berat timbal $(\mathrm{Pb})$ di udara dan upaya penghapusan bensin bertimbal. Berita Dirgantara 3:95-101.

Harlia E, Yuli A, Eulies TM. 2006. Deteksi Logam Berat Kadmium (Cd) dalam Hati Ayam Buras dan Upaya Reduksi Secara Fisik (Penggorengan) dan Kimiawi (Penggunaan Filtrate Belimbing Wuluh). Lokakarya Nasional Keamanan Pangan Produk Peternakan.

Horky D, Illek J, Pechova A. 1998. Distribution of heavy metals in calf organs. Vet Med. 43:331342.

Iwegbue CMA, Nwajei GEN, Iyoha EH. 2008. Heavy metal residues of chicken meat and gizzard and turkey meat consumed in southern Nigeria. Bulg J Vet Med. 11:275-280.

John HH, Jeanne IR. 1994. Food Additives, Contaminants and Natural Toxins. In: Maurice ES, James AO, Moshe SL, Febiger, editors. Modern Nutrition in Health and Disease. 8th edition, Part II. p. 1597-1598. 
Nwude, Wu J, Hopkins DG, Welch RH. 2010. Division S-8-Nutrient management \& soil \& plant analysis: Association of cadmium in durum wheat grain with soil chloride and chelateextractable soil cadmium. Soil Sci Soc Am J. 64:2162-2168.

Ogabiella, Master DG, White CL, Grace ND, Judson GJ. 2010. Current issues in trace element nutrition of grazing livestock in Australia and New Zealand. J Agric Res. 50:1341-1354.

Palar H. 2004. Pencemaran dan Toksikologi Pencemaran Logam Berat. Jakarta (Indoneia): Rineka Cipta.

Sudarmaji, Mukono J, Corie IP. 2006. Toksikologi logam berat B3 dan dampaknya terhadap kesehatan. J Kes Ling. 2:129-142.

Sudarmono AS, Sugeng YB, 1993. Beternak Domba. Jakarta (Indonesia): Penebar Swadaya.

Wardhayani S, Setiani O, Hanani YD. 2006. Analisis risiko pencemaran bahan toksik timbal $(\mathrm{Pb})$ pada sapi potong di Tempat Pembuangan Akhir (TPA) sampah Jatibarang Semarang. J Kes Ling Indonesia.

\section{DISCUSSION}

\section{Questions}

1. What kind of garbage do you give to the sheep?

2. The number of sheep you analyzed were limited and generated less representative. How do you conclude your research?

\section{Answers}

1. There's no feeding treatment to the first two lambs. Selected lambs are known grazing in the area of landfill area from birth so they consuming everything in the landfills. The types of garbage that may exists in that landfill area can be divided into inorganic and organic waste included domestic waste, plastic, cans, batteries and other industrial waste. In addition on the landfills area we also found a black water puddles which usually use as a source of drinking water to that cattle. The first two sheep are slaughtered and some organs are taken. Those organs are tested for the presence of residues of heavy metals using Atomic Absorption Spectrophotometer (AAS). Two last sheep are taken from the landfill area and placed in grassland and grazed as usual. The second group of sheep are fed of elephant grass and commercial concentrate. After 3 months the second group of sheep are slaughtered and some organs which are similar to the first group of sheep are taken and tested to the heavy metal residues by using $A A S$

2. The two-sample t-test is valid if the two samples are independent simple random samples from Normal distributions with the same variance and each of the sample sizes is at least two (so that the population variance can be estimated.) Considerations of power are irrelevant to the question of the validity of the test. Depending upon the size of the effect that one wishes to detect, a small sample size may be imprudent, but a small sample size does not invalidate the test 